\title{
Professional safety constructs in the context of Primary Health Care
}

\author{
Constructos da segurança do profissional no contexto da Atenção Primária à Saúde \\ Construcciones de seguridad profesional en el contexto de la Atención Primaria de Salud
}

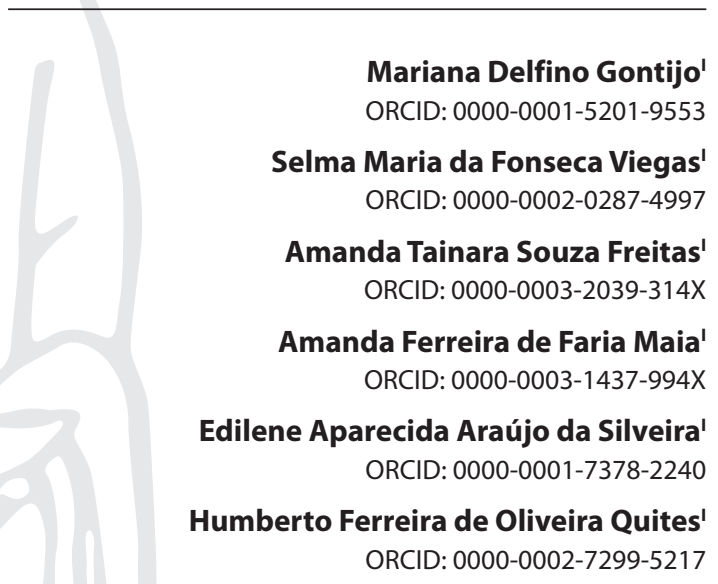

'Universidade Federal de São João del-Rei. Divinópolis, Minas Gerais, Brazil.

How to cite this article: Gontijo MD, Viegas SMF, Freitas ATS, Maia AFF, Silveira EAA, Quites HFO. Professional safety constructs in the context of Primary Health Care. Rev Bras Enferm. 2020;73(Suppl 6):e20190529. doi: http://dx.doi.org/10.1590/0034-7167-2019-0529

Corresponding author: Selma Maria da Fonseca Viegas E-mail: selmaviegas@ufsj.edu.br

EDITOR IN CHIEF: Dulce Barbosa ASSOCIATE EDITOR: Hugo Fernandes

Submission: 04-15-2019

Approval: 04-26-2020

\begin{abstract}
Objectives: to identify scientific production on safety-related aspects/characteristics in the performance of Primary Health Care professionals for professional safety constructs. Methods: integrative literature review in the BDENF, IBECS, LILACS, MEDLINE databases. Results: the corpus of this review refers to 16 articles that highlighted work overload, work process, insufficient human resources, precarious work environment conditions, lack of continuing education, team relationship and with users, evidencing that they are factors that possibly compromise health care and professional safety for best practices. Final Considerations: to know the factors that impact in the scope of professional safety allows to subsidize interventions that guarantee best practices. This study originally contributes to the formulation of Primary Health Care professional safety constructs.

Descriptors: Primary Health Care; Health Personnel; Safety Management; Working Conditions; Patient Safety.
\end{abstract}

\section{RESUMO}

Objetivos: identificar a produção científica sobre os aspectos/características relacionadas à segurança na atuação dos profissionais da Atenção Primária à Saúde para constructos da temática Segurança do Profissional. Métodos: revisão integrativa da literatura nas bases de dados BDENF, IBECS, LILACS, MEDLINE. Resultados: o corpus desta revisão refere-se a 16 artigos que destacaram a sobrecarga de trabalho, processo de trabalho, recursos humanos insuficientes, condições precárias do ambiente de trabalho, falta de Educação Permanente, inter-relação em equipe e com usuários, evidenciando que são fatores que possivelmente comprometem a assistência à saúde e a Segurança do Profissional para boas práticas. Considerações Finais: conhecer os fatores que impactam no âmbito da Segurança dos Profissionais permite subsidiar intervenções que garantam as boas práticas. Este estudo contribui originalmente para formulação dos constructos da Segurança do Profissional da Atenção Primária à Saúde.

Descritores: Atenção Primária à Saúde; Pessoal de Saúde; Gestão da Segurança; Condições de Trabalho; Segurança do Paciente.

\section{RESUMEN}

Objetivos: identificar la producción científica sobre aspectos/características relacionadas con la seguridad en el desempeño de los profesionales de la Atención Primaria de Salud para construcciones sobre el tema de la seguridad del profesional. Métodos: revisión integradora de la literatura en las bases de datos BDENF, IBECS, LILACS, MEDLINE. Resultados: el corpus de esta revisión se refiere a 16 artículos que destacaron la sobrecarga de trabajo, el proceso de trabajo, los recursos humanos insuficientes, las malas condiciones del entorno laboral, la falta de educación permanente, la interrelación del equipo y el usuario, lo que demuestra que son factores que posiblemente comprometan la atención médica y la seguridad profesional para las buenas prácticas. Consideraciones Finales: conocer los factores que impactan en la seguridad del profesional permite subsidiar intervenciones que garantizan buenas prácticas. Este estudio originalmente contribuyó a la formulación de las construcciones de seguridad profesional de la Atención Primaria de Salud.

Descriptores: Atención Primaria de Salud; Personal de Salud; Administración de la Seguridad; Condiciones de Trabajo; Seguridad del Paciente. 


\section{INTRODUCTION}

The performance of health professionals is present in several fields and services, covering all levels of complexity. The object of health care and care is independent of the field of action, being centered on the human being, with different needs, particularities and singularities, which demands the professional to make safe decisions/actions and best practices. Safety for performance requires of the professional accurate and reliable evaluation of actions, implementation of strategies to report real or potential unsafe care and errors ${ }^{(1-3)}$.

Given this scenario of best practices to provide safety, the Brazilian National Program for Patient Safety (Programa Nacional de Segurança do Paciente, abbreviated PNSP) was launched in Brazil and established by the Ministry of Health, which stipulated, among its strategies, promotion of the safety culture as a priority ${ }^{(1)}$. This is defined as a "set of individual and collective characteristics, competencies, behaviors and questions, culminating in attitudes and practices around the willingness to detect and learn from errors"(2).

It advocates basic protocols of safety to the patient in the provision of care from the perspective of the multidisciplinary team, defined that, in order to establish a safe care, it is necessary to build a safety culture in which all professionals involved in care and managers take responsibility for their own safety, for the safety of their colleagues, patients and family members ${ }^{(1)}$.

The safety culture determines how security is managed by the institution and professionals, through behaviors, attitudes, values, and perceptions, which help shape their commitment to safety ${ }^{(4)}$.

Safe care and care derive both from the correct actions of health professionals, as well as from appropriate processes and systems in institutions and services, as well as from regulatory government policies, establishing a coordinated and permanent effort ${ }^{(5)}$.

When thinking about a safety culture in health and Primary Health Care (PHC), it is observed that error is very associated with guilt, a punitive work environment and a culture of thinking that errors caused by health care providers are the result of carelessness. Thus, it is necessary to strengthen the security climate in this context, since error is considered less relevant ${ }^{(6)}$.

Professional safety and best practices are essential for safe care. Some factors can minimize actions or influences on incidents, which are: "human, related to the professional; related to the work environment; related to factors outside the governability of the manager; and those related to the patient, for example, non-adherence to treatment"(2). However, despite the primacy of safe practice, few studies have been observed in relation to professional safety. Researchers have focused much more on the patient safety climate than on the professional safety climate. The safety climate is defined as "perceptions of employees about the relative importance of safe conduct in their occupational behavior"(7).

Some factors may compromise professional safety such as failures in interprofessional communication and with patients; management failures (lack of inputs, professionals pressured to be more productive in less time, inadequate physical structure, excessive tasks and care failures). Strategies to mitigate these factors can be used such as: disclosing safe practices; adapting physical structures; training health team professionals; improving inter-professional communication; improving management of health units; allowing users/citizens and professionals to recognize and manage adverse events; empowering health professionals to share changes in the team to identify and act in risk situations; motivating health professionals to act towards safety; participation of all professionals in management decisions; creating professional performance evaluation systems ${ }^{(6)}$.

The daily work is permeated by new ways of doing health in a complex work context. The work context refers to the social space where organization and working conditions operate, as well as socio-professional relations ${ }^{(8)}$. Several studies show that this context presents factors that culminate in increased workload, impacting on professional safety and, consequently, patient safety ${ }^{(3,9-12)}$.

Thus, it is questioned: how has the scientific literature investigated issues related to professional safety?

\section{OBJECTIVES}

To identify scientific production on safety-related aspects/ characteristics in the performance of PHC professionals for professional safety constructs.

\section{METHODS}

This is an integrative review, for the broad and systematic analysis of contributions in the literature, aiming at gathering and synthesizing, in an orderly manner, the results of research on the context of the professional's performance and their safety to work in PHC. The reviews integrate a diversity of knowledge through the use of rigorous methods, which have the potential to gather the findings of studies developed through different methodologies, contributing to the deepening of the investigated theme ${ }^{(13)}$.

This integrative review was carried out following the steps: identification of the theme and selection of the research question; establishment of eligibility criteria; identification of studies on scientific bases; evaluation of selected studies and critical analysis; categorization of studies; analysis and synthesis of data, considering the meanings of professional safety in PHC; evaluation and interpretation of results; and presentation of results in the framework of the integrative review ${ }^{(14)}$. To guide the development of the study, the following guiding question was used: what aspects and/or characteristics are related to safety for PHC professional workers?

Operationalization of this research began with a consultation with the Health Sciences Descriptors (Descritores em Ciências da Saúde, abbreviated DeCS), through the Virtual Health Library (VHL); and Medical Subject Headings (MeSH) of National Library, for knowledge of universal descriptors. Therefore, the controlled descriptors were used in Portuguese and English: "Atenção Primária à Saúde/Primary Health Care"; "Pessoal de Saúde/Health Personnel"; "Gestão da Segurança/Safety Management"; "Enfermeiras e Enfermeiros/Nurses"; "Condições de Trabalho/Working Conditions"; "Segurança do Paciente/Patient Safety", "Assistência à Saúde/Delivery of Health Care". 
The articles were identified through bibliographic search, conducted between April and May 2018, in the following databases: Specific Nursing Sciences Database (BDENF), Spanish Bibliographic Index of Health Sciences (Índice Bibliográfico Espanhol de Ciências da Saúde, abbreviated IBECS), Latin American \& Caribbean Literature in Health Sciences (Literatura Latino-Americana e do Caribe em Ciências da Saúde, abbreviated LILACS), Medical Literature Analysis and Retrieval System Online (MEDLINE), consulted by the Virtual Health Library $(\mathrm{VHL})$ and Medical Literature Analysis and Retrieval System Online (MEDLINE), consulted through PubMed, Scientific Electronic Library Online, Web of Science, Scopus accessed by CAPES Portal.

The following inclusion criteria were defined: articles published in full, available electronically in English, Spanish, and Portuguese, between 2014 and 2018, and that contemplated the theme. There was exclusion of theoretical or reflection articles.

The search strategy in the databases used the combination of the following terms: "Patient Safety" AND "Health Personnel" AND "Safety Management" AND "Primary Health Care"; "Health Personnel" AND "Primary Health Care" AND "Safety Management"; "Working Conditions" AND "Primary Health Care"; "Security Management" AND "Nurses"; "Primary Health Care" AND"Patient Safety" AND"Health Care".

Search of articles consisted of advanced search in the databases, detailing the quantity of the articles that met the established inclusion criteria: LILACS (93 articles), BDENF (18 articles), IBECS (07 articles), MEDLINE/PubMed (281 articles), Scielo (25 articles), Web of Science 0, Scopus 0, totaling 424 articles. Then, a refinement was performed, according to the inclusion criteria established and the exclusion of repeated publications. It is noteworthy that this integrative review study also comprises Ordinance 529, of April 1, 2013, the reference document for PNSP and references that address the method of integrative review.

After the process of selection and identification of the articles, there was a previous reading of all titles, abstracts, and 16 publications were elected: LILACS 06, BDENF 03, MEDLINE/PubMed 07 , which were read in full. All 16 articles that met all the criteria and adapted to the objective of this study were selected for the final analysis.

For data organization, the researchers developed a data collection instrument containing: number, title, year, database, type of study/Level of Evidence, objective of the study, main results or conclusions. The classification proposed by Melnyk and Fineout Overholt was used for classification of articles, which consists of seven levels: Level I - evidence stemming from systematic reviews or meta-analysis of relevant clinical trials; Level II - evidence derived from at least one well-outlined randomized controlled trial; Level III - well-outlined clinical trials without randomization; Level IV well-outlined cohort and case-control studies; Level V - systematic review of descriptive and qualitative studies; Level VI - evidence derived from a single descriptive or qualitative study; and Level $\mathrm{VII}$ - opinion of authorities or expert committee report ${ }^{(15)}$, which will be presented in summary in Charts 1 and 2. Classification by Levels of Evidence is justified, because integrative review allows critical evaluation and synthesis of the available evidence on the investigated theme. Concerning professional safety, no published evidence was found, but related themes. Although the articles of integrative and bibliographic review did not meet the criteria for classification by Level of Evidence adopted, three were included and were relevant in this study, due to the scarcity of studies that approach the theme under investigation.

Content of publications was thoroughly analyzed, interpreted and synthesized in a synoptic table, with description of title, year, country, method, Level of Evidence, interventions and outcomes, main results or conclusions, and was finalized with the writing of this review.

\section{RESULTS}

Chart 1 presents the overview of the 16 selected publications, highlighting the characterization, methodological aspects and results of the articles listed.

Of the 16 articles that met the inclusion criteria to achieve the proposed objective, the largest number were MEDLINE (44.00\%), following LILACS (37.00\%), and BDENF (19.00\%). There was a predominance of the English language (50.00\%), present in eight publications, followed by seven articles published in 
Portuguese and one in Spanish. In relation to year of publication, 2016 prevailed (37.50\%), present in six articles, followed by 2015 (31.25\%), 2014 (18.75\%), 2017, and 2018 (6.25\%) Each.

The articles were from Brazil (56.00\%), Iran (13.00\%), England (6.25\%), United States of America (6.25\%), Scotland (6.25\%), Norway (6.25\%), and Chile (6.25\%). Concerning the type of study, there was a predominance of the qualitative study, with six articles; followed by four review articles (one systematic review, two integrative and one bibliographic); three cross-sectional study articles; a multicenter study article; a methodological study; and a case study.

In relation to the types of studies included, Level of Evidence $V$ prevailed in $50.00 \%$ of the selected sample (six qualitative studies, one multicenter study, one systematized review), followed by Level of Evidence IV in $18.75 \%$ (three cross-sectional studies), Level of Evidence VI in $12.50 \%$ (one case study, one methodological study). Eighteen point seventy-five percent were not classified in relation to the Level of Evidence (three review studies).

Chart 1 - Studies included in the integrative review according to outlining, number of participants, level of evidence, objective, and results, 2018

\begin{tabular}{|c|c|c|c|c|}
\hline No & $\begin{array}{l}\text { Title } \\
\text { Year/ } \\
\text { Country }\end{array}$ & $\begin{array}{l}\text { Outlining } \\
\text { Number of Patients/ } \\
\text { Level of evidence }\end{array}$ & Study objective & Results \\
\hline 1 & $\begin{array}{l}\text { Satisfação e insatisfação no } \\
\text { trabalho de profissionais } \\
\text { de saúde da atenção básica } \\
\text { 2014/ } \\
\text { Brazil }\end{array}$ & $\begin{array}{l}\text { Qualitative study } \\
22 \text { participants } \\
\text { Level V }\end{array}$ & $\begin{array}{l}\text { To identify the reasons for } \\
\text { satisfaction and dissatisfaction } \\
\text { of health professionals in the } \\
\text { Family Health Strategy and } \\
\text { traditional primary care. }\end{array}$ & $\begin{array}{l}\text { Reasons for satisfaction: affinity with the profession; } \\
\text { user satisfaction with assistance; teamwork; between } \\
\text { professionals and users. } \\
\text { Reasons for dissatisfaction: problems in relationships } \\
\text { with users/families; insufficient salary; difficulties in } \\
\text { teamwork; deficit of instruments and infrastructure, } \\
\text { excessive workload; and lack of understanding of the } \\
\text { population about the assumptions of Family Health } \\
\text { Strategy. }\end{array}$ \\
\hline 2 & $\begin{array}{l}\text { Trabalho na Estratégia } \\
\text { Saúde da Família: } \\
\text { Implicações nas cargas } \\
\text { de trabalho de seus } \\
\text { profissionais } \\
2014 / \\
\text { Brazil }\end{array}$ & $\begin{array}{l}\text { Qualitative study } \\
11 \text { Participants } \\
\text { Level V }\end{array}$ & $\begin{array}{l}\text { To identify aspects of work at } \\
\text { Family Health Strategy that } \\
\text { contribute to increasing and/ } \\
\text { or reducing workloads. }\end{array}$ & $\begin{array}{l}\text { The aspects that interfere with the proper } \\
\text { implementation of Family Health Strategy increase } \\
\text { workload. } \\
\text { Affinity with work, team autonomy, and job security } \\
\text { reduce workload. }\end{array}$ \\
\hline 3 & $\begin{array}{l}\text { Practice Transformation } \\
\text { in the Safety Net Medical } \\
\text { Home Initiative: A } \\
\text { Qualitative Look }{ }^{(17)} \\
\text { 2014/ } \\
\text { USA }\end{array}$ & $\begin{array}{l}\text { Qualitative case study } \\
07 \text { participants } \\
\text { Level VI }\end{array}$ & $\begin{array}{l}\text { To study three successful } \\
\text { practices to identify } \\
\text { common characteristics and } \\
\text { approaches. }\end{array}$ & $\begin{array}{l}\text { They were motivators of successful practices: desire to } \\
\text { improve the quality of care and the experience of the } \\
\text { patient or professional. Financial incentives played a } \\
\text { minor role. }\end{array}$ \\
\hline 4 & $\begin{array}{l}\text { Work context, job } \\
\text { satisfaction and suffering in } \\
\text { primary health care }{ }^{(8)} \\
2015 / \\
\text { Brazil }\end{array}$ & $\begin{array}{l}\text { Cross-sectional study } \\
242 \text { participants } \\
\text { Level IV }\end{array}$ & $\begin{array}{l}\text { To evaluate the work context } \\
\text { and the indicators of pleasure } \\
\text { and suffering from the } \\
\text { perspective of workers. }\end{array}$ & $\begin{array}{l}\text { Organization and working conditions obtained the } \\
\text { worst evaluations. } \\
\text { Indicators of pleasure at work were related to } \\
\text { professional achievement, freedom of expression, and } \\
\text { acknowledgment. }\end{array}$ \\
\hline 5 & $\begin{array}{l}\text { Dimensions of Safety } \\
\text { Climate among Iranian } \\
\text { Nurses }{ }^{(7)} \\
2015 / \\
\text { Iran }\end{array}$ & $\begin{array}{l}\text { Literature review } \\
\text { Not quantified and } \\
\text { not classified in } \\
\text { relation to the Level } \\
\text { of Evidence }\end{array}$ & $\begin{array}{l}\text { To develop and validate } \\
\text { a psychometric scale to } \\
\text { measure the safety climate of } \\
\text { nurses. }\end{array}$ & $\begin{array}{l}\text { A scale of } 40 \text { items with } 6 \text { dimensions was elaborated: } \\
1 \text { - involvement of employees in security support and } \\
\text { management; } 2 \text { - compliance with safety rules; } 3 \text { - training } \\
\text { and accessibility to personal protective equipment; } \\
\text { 4-obstacles to safe work; } 5 \text { - communication safety and } \\
\text { working pressure; } 6 \text { - and individual risk perception. }\end{array}$ \\
\hline 6 & $\begin{array}{l}\text { Ser enfermeiro da Estratégia } \\
\text { Saúde da Família: desafio e } \\
\text { possibilidades } \\
\text { 2015/ } \\
\text { Brazil }\end{array}$ & $\begin{array}{l}\text { Qualitative study/ } \\
07 \text { participants } \\
\text { Level V }\end{array}$ & $\begin{array}{l}\text { To analyze the challenges } \\
\text { and possibilities of the work } \\
\text { of nurses in Family Health } \\
\text { Strategy in a health district of } \\
\text { Belo Horizonte. }\end{array}$ & $\begin{array}{l}\text { The daily life of nurses at Family Health Strategy } \\
\text { is marked by work overload, which impairs the } \\
\text { performance of actions. }\end{array}$ \\
\hline 7 & $\begin{array}{l}\text { Safety climate in English } \\
\text { general practices; workload } \\
\text { pressures may compromise } \\
\text { safety } \\
2015 / \\
\text { England }\end{array}$ & $\begin{array}{l}\text { Cross-sectional study } \\
335 \text { participants } \\
\text { Level IV }\end{array}$ & $\begin{array}{l}\text { To build an instrument for } \\
\text { general British patient safety } \\
\text { practices. } \\
\text { To report how these practices } \\
\text { affect the security climate and } \\
\text { high workload levels. }\end{array}$ & $\begin{array}{l}\text { Managers gave their practices significantly higher } \\
\text { safety scores than non-manager participants. } \\
\text { Respondents with more years of experience had a } \\
\text { more negative perception of the level of workload. } \\
\text { Practices with patients living in areas of greater } \\
\text { deprivation provided lower scores in relation to the } \\
\text { safety climate. }\end{array}$ \\
\hline 8 & $\begin{array}{l}\text { Dealing with workplace } \\
\text { violence in emergency } \\
\text { primary health care: a focus } \\
\text { group study }{ }^{(18)} \\
2015 / \\
\text { Norway }\end{array}$ & $\begin{array}{l}\text { Qualitative study/ } \\
37 \text { participants } \\
\text { Level V }\end{array}$ & $\begin{array}{l}\text { To explore how the Primary } \\
\text { Health Care professional } \\
\text { handled the threats and } \\
\text { violence of visitors or patients. }\end{array}$ & $\begin{array}{l}\text { Threatening situations that generated insecurity } \\
\text { were related to family members, with fewer physical } \\
\text { aggressions. } \\
\text { Factors that influence threats or violence: to minimize } \\
\text { the risk of working alone; to be prepared; to resolve } \\
\text { the mismatch between the patient's expectations and } \\
\text { the service offered; and management support. }\end{array}$ \\
\hline
\end{tabular}




\begin{tabular}{|c|c|c|c|c|}
\hline No & $\begin{array}{l}\text { Title } \\
\text { Year/ } \\
\text { Country }\end{array}$ & $\begin{array}{l}\text { Outlining } \\
\text { Number of Patients/ } \\
\text { Level of evidence }\end{array}$ & Study objective & Results \\
\hline 9 & $\begin{array}{l}\text { Iranian nurses perspectives } \\
\text { on assessment of safe care: } \\
\text { an exploratory study }{ }^{(3)} \\
2016 / \\
\text { Iran }\end{array}$ & $\begin{array}{l}\text { Qualitative study/ } \\
16 \text { participants } \\
\text { Level V }\end{array}$ & $\begin{array}{l}\text { To explore the perspectives } \\
\text { and experiences of nurses on } \\
\text { the evaluation of safe nursing } \\
\text { care and clinical practice. }\end{array}$ & $\begin{array}{l}\text { Four components were identified for safe care and } \\
\text { patient safety: holistic evaluation of nursing care; } \\
\text { teamwork and evaluation of nursing care; ethical } \\
\text { problems; and challenges of safe evaluation of } \\
\text { nursing care. }\end{array}$ \\
\hline 10 & $\begin{array}{l}\text { Condiciones de trabajo de } \\
\text { los profesionales } \\
\text { de enfermería en Chile } \\
\text { 2016/ } \\
\text { Chile }\end{array}$ & $\begin{array}{l}\text { Systematic review } \\
\text { of descriptive } \\
\text { and retrospective } \\
\text { character/ } 9 \text { articles } \\
\text { Level V }\end{array}$ & $\begin{array}{l}\text { To identify working conditions } \\
\text { and the reasons why nursing } \\
\text { professionals get sick. }\end{array}$ & $\begin{array}{l}\text { Nursing professionals work in conditions marked by } \\
\text { lack of materials, work overload and limited resources. }\end{array}$ \\
\hline 11 & $\begin{array}{l}\text { Patient safety in Primary } \\
\text { Health Care: integrative } \\
\text { review }^{(6)} \\
2016 / \\
\text { Brazil }\end{array}$ & $\begin{array}{l}\text { Integrative review/ } \\
10 \text { articles/ } \\
\text { Not classified in } \\
\text { relation to the Level } \\
\text { of Evidence }\end{array}$ & $\begin{array}{l}\text { To analyze scientific } \\
\text { productions on patient safety. }\end{array}$ & $\begin{array}{l}\text { Scientific production related to the theme of patient } \\
\text { safety has been increasing in recent years, following } \\
\text { the discussions and intentions of the World Health } \\
\text { Organization. }\end{array}$ \\
\hline 12 & $\begin{array}{l}\text { Cuidados de enfermagem } \\
\text { no pré-natal e segurança } \\
\text { do paciente: revisão } \\
\text { integrativa }{ }^{(5)} \\
2016 / \\
\text { Brazil }\end{array}$ & $\begin{array}{l}\text { Integrative review/ } \\
280 \text { articles/ } \\
\text { Not classified in } \\
\text { relation to the Level } \\
\text { of Evidence }\end{array}$ & $\begin{array}{l}\text { To analyze the publications } \\
\text { on patient safety during } \\
\text { nursing care in prenatal care } \\
\text { of Primary Health Care. }\end{array}$ & $\begin{array}{l}\text { Expansion of Family Health Strategy coverage and } \\
\text { professional training can be strategies to qualify } \\
\text { health care for safe and quality care for women in } \\
\text { prenatal care. }\end{array}$ \\
\hline 13 & $\begin{array}{l}\text { Aumento das cargas de } \\
\text { trabalho em técnicos de } \\
\text { enfermagem na Atenção } \\
\text { Primária à Saúde no Brasil(11) } \\
\text { 2016/ } \\
\text { Brazil }\end{array}$ & $\begin{array}{l}\text { Multi-Institutional } \\
\text { Clinical Trial } \\
24 \text { professionals/ } \\
\text { Level V }\end{array}$ & $\begin{array}{l}\text { To analyze the aspects } \\
\text { that contribute to increase } \\
\text { workload of nursing } \\
\text { technicians. }\end{array}$ & $\begin{array}{l}\text { Aspects that contribute to increase workload: low } \\
\text { remuneration, lack of material resources, wear and } \\
\text { illness, relationship with the user and scarcity of } \\
\text { human resources. Prevailing overloads related to } \\
\text { psychic and physiological conditions. }\end{array}$ \\
\hline 14 & $\begin{array}{l}\text { Qualitative evaluation of the } \\
\text { Safety and Improvement } \\
\text { in Primary Care (SIPC) pilot } \\
\text { collaborative in Scotland: } \\
\text { perceptions and experiences } \\
\text { of participating care teams }{ }^{(19)} \\
\text { 2016/ } \\
\text { Scotland }\end{array}$ & $\begin{array}{l}\text { Qualitative study/ } \\
27 \text { participants/ } \\
\text { Level V }\end{array}$ & $\begin{array}{l}\text { To explore participants' } \\
\text { perceptions and experiences } \\
\text { about security. To identify } \\
\text { facilitators and barriers to } \\
\text { improving safety. }\end{array}$ & $\begin{array}{l}\text { The results indicated benefits of using the program; } \\
\text { improvements in patient care systems; usefulness of } \\
\text { program interventions. }\end{array}$ \\
\hline 15 & $\begin{array}{l}\text { Prevalência da capacidade } \\
\text { para o trabalho inadequada } \\
\text { entre trabalhadores de } \\
\text { enfermagem da atenção } \\
\text { básica à saúde } \\
2017 / \\
\text { Brazil }\end{array}$ & $\begin{array}{l}\text { Cross-sectional } \\
\text { study/ } \\
490 \text { participants/ } \\
\text { Level IV }\end{array}$ & $\begin{array}{l}\text { To describe the prevalence } \\
\text { and characteristics of } \\
\text { inadequate work capacity } \\
\text { among nursing workers in the } \\
\text { State of Bahia. }\end{array}$ & $\begin{array}{l}\text { Prevalence of inadequate work capacity was } 17.9 \% \text {, } \\
\text { being higher among nurses ( } 18.2 \%) \text {, when compared } \\
\text { to nursing technicians and assistants (17.7\%). } \\
\text { Changes are necessary both in the work environment } \\
\text { and in the life of the worker. }\end{array}$ \\
\hline 16 & $\begin{array}{l}\text { Validation of a moral } \\
\text { distress instrument } \\
\text { in nurses of primary health } \\
\text { care (21) } \\
2018 / \\
\text { Brazil }\end{array}$ & $\begin{array}{l}\text { Methodological } \\
\text { study/ } \\
391 \text { participants/ } \\
\text { Level VI }\end{array}$ & $\begin{array}{l}\text { To validate an instrument to } \\
\text { identify the situations that } \\
\text { triggered moral distress in } \\
\text { nurses. }\end{array}$ & $\begin{array}{l}\text { Forty-six questions were validated, divided into } \\
\text { six constructs: health policies, working conditions, } \\
\text { nurse autonomy, professional ethical competence, } \\
\text { disrespect for user autonomy and work overload. }\end{array}$ \\
\hline
\end{tabular}

\section{DISCUSSION}

The professional's performance is understood in different ways by the researchers, one of them in relation to the ability to work, however, it almost always refers to the idea of the balance between stress related to working conditions, the work environment and its tools and the worker's wear caused by stress ${ }^{(20)}$.

Some studies address the workload among health professionals and present factors that impact actions, among them, low monthly remuneration, lack of material resources for care, work overload, physical suffering, relationship with users, and scarcity of human resources ${ }^{(3,10-12)}$. These are factors that can interfere in professional safety for best health practices and $\mathrm{PHC}$, causing negative impacts on the management of necessary processes, engagement of professionals, demands of time and difficulties in communication, compromising quality care ${ }^{(17)}$.

Work overload, lack of staff and poor team performance result in emotional exhaustion, leading to professional error ${ }^{(3)}$. Other studies present aspects that provide dissatisfaction at work in $\mathrm{PHC}$, which are: difficulties in collaboration of users, families and the community in the care process; difficulties in relationships to perform teamwork; precarious working conditions; lack of working tools; inadequate physical area of the units, scarce number of professionals; the training of teams to meet the needs presented by users and the lack of investment in continuing education ${ }^{(10,16)}$. These factors and aspects go against the axes and measures for best practices in health and PHC. 
Associated with this context, a study evidences some factors responsible for triggering moral distress of $\mathrm{PHC}$ professionals, which are: health policies, working conditions, autonomy and professional ethical competence, disrespect for user autonomy and work overload. These factors lead to suffering, consequently causing poor quality of care ${ }^{(21)}$, interfering with professional safety and, consequently, PHC patient/user safety.

Furthermore, professionals working in PHC face structural limitations that include the physical structure of inadequate services and difficulties in performing and receiving exams and results. It is a fact that, in order to provide quality and safety care, structural and procedural subsidies are needed to provide professionals with the conditions to ensure quality care ${ }^{(5)}$.

All factors and aspects described have an influence on the quality of the services provided and put at risk the guarantee of the guidelines and principles guaranteed by SUS (Sistema Único de Saúde - Brazilian Unified Health System) such as access, equity and comprehensiveness in public health care ${ }^{(10)}$.

The desire to improve the quality of care and the experience of professionals and patients are factors that contribute to successful practices, considering that, for this, it is necessary to raise awareness by organizations, in order to enable improvements in infrastructure and the system ${ }^{(17)}$. In a study conducted on safe care assessment, it was observed that carrying out safe care is related to the perception that professionals have on the subject ${ }^{(3)}$. To change and improve practices, one needs the will or motivation of professionals to eradicate old processes and habits and try new ones.

Change seems to be easier if based on explicit ideas that have been tried and considered successful elsewhere. However, motivation and good ideas are insufficient if the practice does not have a strategy and mechanisms for to carry out significant changes to the practice and work processes ${ }^{(17)}$.

Acting in different health contexts is associated with exposure to high risks of violence in the workplace, whether generated by patients or visitors. Understanding how professionals deal with violent incidents can point to factors that indicate how to reduce the risk of working alone, be attentive to the work environment, know how to deal with users' expectations regarding the services offered and establish great communication with the whole team, in order to enable the prevention and reduction of violence in the workplace. In view of this scenario, prevention and administrative measures should be considered in order to ensure the protection of employees against violence and threats ${ }^{(18)}$.

Raising awareness of the safety climate improves overall practice and, consequently, safety ${ }^{(4)}$. It is necessary to warn about the negative impacts on health care and enable the safety culture, expanding the concepts of improvement and risk management ${ }^{(19)}$.
In this context, it is essential to conduct new studies that address the safety culture, professional safety, and influence of professional safety in PHC.

\section{Study limitations}

Limitation occurred was due to delimitation of the period between 2014 and 2018, conferring 16 articles for this review. The justification for delimitation of this period is the publication of Ordinance 529 of April 1, 2013 instituted PNSP, which among its strategies, promotion of the safety culture becomes a priority.

\section{Contributions to the field}

This study originally contributes to the understanding of the context of health professionals' performance in PHC and the knowledge of factors that influence professional safety and formulation of professional safety constructs. No studies were found that address the analysis of factors directly associated with safety in the performance of health professionals in PHC, but it is considered that the included studies address related subjects to develop constructs for the theme under study.

\section{FINAL CONSIDERATIONS}

Although the literature presents studies on patient safety and safety culture, the context of safety in the performance of PHC professionals has not yet been consistently explored. There are few studies that refer to this theme so relevant in the daily life of services and health professionals, signaling the need for studies on professional safety.

A fine relationship can be identified between the quality of patient safety care and factors that hinder or compromise best practices of PHC professionals. It was evident, in the analyzed studies, that professional safety constructs are more associated with care management than with direct care to users. Best practices and safety in the context of PHC depend on the skills and competences of professionals; improvements in working conditions and organization of daily work; adequate infrastructure for the performance of functions; sufficient human resources for the demand of service and users; management support; continuing education.

Thus, this review supports the construction of knowledge in professional safety by enabling the structuring of constructs of this approach in the context of action in PHC.

The development of research aimed at understanding professional safety in the context of PHC, since the relationship between quality of care and patient safety is directly related to professional safety.

\section{REFERENCES}

1. Ministério da Saúde (BR). Portaria n529, de $1^{\circ}$ de abril de 2013. Institui o Programa Nacional de Segurança do Paciente (PNSP) [Internet]. Diário Oficial da União, Brasília (DF);2013 [cited 2018 May 31]. Available from: http://bvsms.saude.gov.br/bvs/saudelegis/gm/2013/prt0529_01_04_2013.html

2. Ministério da Saúde (BR). Documento de Referência para o Programa Nacional de Segurança do Paciente [Internet]. Brasília (DF): MS; $2014[$ [cited 2018 May 31]. Available from: http://bvsms.saude.gov.br/bvs/publicacoes/documento_referencia_programa_nacional_seguranca.pdf 
3. Rashvand F, Salsali M, Ebadi A, Vaismoradi M, Jordan S, Griffiths P. Iranian nurses perspectives on assessment of safe care: an exploratory study. J Nurs Manag. 2016;24(3):417-26. doi: 10.1111/jonm.12338

4. Bell BG, Reeves D, Marsden K, Avery A. Safety climate in English general practices: workload pressures may compromise safety. J Eval Clin Pract. 2016;22(1):71-6. doi: 10.1111/jep.12437

5. Costa DKP, Arruda LP, Magalhães AHR, Abreu, LDP, Ponte KMA, Freitas CHA. Nursing care in prenatal and patient safety: integrative review. Rev Enferm UFPE. 2016;10(6):4909-4919. doi: 10.5205/1981-8953-v10i6a11272p4909-4919-2016

6. Mesquita KO, Silva LCC, Lira RCM, Freitas CASL, Lira GV. Patient safety in primary health care: an integrative review. Cogitare Enferm [Internet]. 2016 [cited 2018 Apr 05];21 (2):1-8. Available from: https://revistas.ufpr.br/cogitare/article/view/45665/28527

7. Kongin NZ, Shokoohi Y, Zarei F, Rahimzadeh M, Sarsangi V. Dimensions of Safety Climate among Iranian Nurses. Int J Occup Environ Med. 2015;6(4):223-31. doi: 10.15171/ijoem.2015.550

8. Maissiat GS, Lautert L, Dal Pal D, Tavares JP. Work context, job satisfaction and suffering in primary health care. Rev Gaúcha Enferm. 2015;36(2):42. doi: 10.1590/1983-1447.2015.02.51128

9. Caçador BS, Brito MJM, Moreira DA, Rezende LC, Vilela CS. Being a nurse in the family health strategy programme: challenges and possibilities. Rev Min Enferm. 2015;19(3):612-61. doi: 10.5935/1415-2762.20150047

10. Trindade LL, Pires DEP, Amestoy SC, Forte ECN, Machado FL, Bordignon M. Working in the Family health strategy: implications in professional workloads. Cogitare Enferm [Internet] 2014 [cited 2018 Apr 10];19(3):528-35. Available from: https://revistas.ufpr.br/cogitare/ article/view/35492/23237

11. Scherer MDA, Oliveira NA, Pires DEP, Trindade LL, Gonçalves ASR, Vieira M. Aumento das cargas de trabalho em técnicos de enfermagem na Atenção Primária à Saúde no Brasil. Trab Educ Saúde. 2016;14(1):89-104. doi: 10.1590/1981-7746-sol00030

12. Vergara CM, Suazo VS, Klijn T. Condiciones de trabajo de los profesionales de enfermería en Chile; Enfermería Universitaria. 2016;13(3):17886. doi: 10.1016/j.reu.2016.05.004

13. Soares CB, Hoga LAK, Peduzzi M, Sangaleti C, Yonekura T, Silva DRAD. Integrative review; concepts and methods udes in nursing. Rev Esc Enferm USP. 2014;48(2):335-45. doi: 10.1590/S0080-6234201400002000020

14. Botelho LLR, Cunha CCA, Macedo MM. O método da revisão integrativa nos estudos organizacionais. Rev Eletr Gestão Soc. 2011;5(11):12136. doi: $10.21171 /$ ges.v5i11.1220

15. Melnik BM, Fineout-Overholt E. Making the case for evidence-based practice and cultivating a spirit of inquiry. In: Melnyk BM, FineoutOverholt E. Evidence-based practice in nursing \& healthcare: a guide to best practice. Philadelphia: Lippincott Williams \& Wilkins; 2005.

16. Lima L, Pires DEP, Forte ECN, Medeiros F. Job satisfaction and dissatisfaction of primary health care professionals. Esc Anna Nery. 2014;18(1):17-24. doi: 10.5935/1414-8145.20140003

17. Wagner EH, Gupta R, Coleman K. Practice transformation in the safety net medical home initiative: a qualitative look. Medical Care. 2014;52:18-22. doi: 10.1097/MLR.0000000000000196

18. Morken T, Johansen I, Alsaker K. Dealing with workplace violence in emergency primary health care: a focus group study. BMC Fam Pract. 2015;16:51. doi: 10.1186/s12875-015-0276-Z

19. Bowie P, Halley L, Blamey A, Gillies J, Houston NH. Qualitative evaluation of the Safety and Improvement in Primary Care (SIPC) pilot collaborative in Scotland: perceptions and experiences of participating care teams. BMJ Open. 2016;6(1):1-10. doi: 10.1136/ bmjopen-2015-009526

20. Cordeiro TMSC, Araújo TM. Prevalência da capacidade para o trabalho inadequada entre trabalhadores de enfermagem da atenção básica à saúde. Rev Bras Med Trab. 2017;15(2):150-7. doi: 10.5327/Z1679443520177004

21. Bart PO, Ramos FRS, Barlem ELD, Dalmolin GL, Schneider, DG. Validation of a moral distress instrument in nurses of primary health care. Rev Latino-Am Enfermagem. 2018;26:e3010. doi: 10.1590/1518-8345.2227.3010 